\title{
HUBUNGAN ANTARA LAMA PEMAKAIAN KB SUNTIK 3 BULAN (DPMA) DENGAN KEJADIAN FLOUR ALBUS PATOLOGIS DI BPS ENDANG, Amd.Keb
}

\author{
Supartini, SKM \\ Prodi D-III Kebidanan Universitas PGRI Adi Buana Surabaya
}

\begin{abstract}
ABSTRAK
Paradigma KB Nasional telah di ubah Visi dan NKKBS menjadi keluarga berkualitas 2015dengan 6 misi yaitu memperdayakan masyarakat untuk membangun keluarga kecil berkualitas,menggalang kemitraan kesejahtraan, kemandirian dan ketahanan keluarga,meningkatkan kualitas pelayanan $\mathrm{KB}$, meningkatkan promosi,perlindungan dan upaya mewujudkan hak-hak reproduksi, meningkatkan upaya perempuan untuk mewujudkan kesejahtraan dan keadilan gender melalui program $\mathrm{KB}$.
\end{abstract}

Tujuan dari penelitian ini adalah menganalisisHubungan antara lama pemakaian KB suntik 3 bulan ( DMPA) dengan kejadian flour albus patologis.

Jenis penelitiananalitic cross sectional,teknik simple random sampling. Besarnya Sampel adalah semua akseptor KB suntik 3 bulan di BPS Ny Endang,Surabaya.Pada bulan Juni -September 2011 yaitu sebesar 25 akseptor.

Hasil penelitian dari hubungan antara lama pemakaian KB suntik 3 bulan dengan kejadian flour albus patologis menunjukan bahwa dari 25 akseptor KB suntik 3 bulan terdapat 21 akseptor $(0,84 \%)$ yang mengalami flour albus patologis dan 4 akseptor $(0,16 \%)$ tidak mengalami flour albus patologis. Hasil perhitungan chi square, nilai $\chi^{2}$ hitung $(0,009) \geq \chi^{2}$ tabel $(3,841)$ berarti $\mathrm{H}_{0}$ ditolak dan $\mathrm{H}_{1}$ diterima.

Kesimpulannya ada hubungan antara lama pemakaian KB suntik 3 bulan dengan kejadian flour albus patologis,untuk itu diharapkan pada petugas kesehatan(bidan) agar memberikan penyuluhan/informasi yang jelas, yang berhubungan dengan kejadian flour albus patologis dan cara penanganannya agar responden dapat memahami dengan baik.

Kata kunci : lama pemakaian.akseptor KB suntik,flour albus patologis

PENDAHULUAN

Paradigma KB Nasional telah di

ubah Visi dan NKKBS menjadi keluarga

berkualitas 2015 dengan 6 misi yaitu

memperdayakan masyarakat untuk

membangun keluarga kecil

berkualitas,menggalang kemitraan

kesejahtraan, kemandirian dan ketahanan keluarga,meningkatkan kualitas pelayanan

$\mathrm{KB}$, meningkatkan promosi,perlindungan

dan upaya mewujudkan hak-hak

reproduksi, meningkatkan upaya

perempuan untuk mewujudkan

kesejahtraan dan keadilan gender melalui program KB. 
Berdasarkan hasil survei WHO pada tahun 2010, berdasarkan pemakaian KB suntik sebesar $31,65 \%, \mathrm{~KB}$ pil sebesar 13,2\%, KB IUD sebesar 4,8\%, KB Implan sebesar 2,8\%,KB MOW sebesar 3,1\%,KB $\mathrm{MOP}$ sebesar 0,2\%,Kondom sebesar $1,3 \%$,pantang berkala $1,5 \%$,senggama putus sebesar $2,2 \%$, dan metode lain $0,4 \%$.

Berdasarkan data di BKKBN Jawa Timur yang diambil dari bulan Januari 2011 tercatat jumlah peserta KB Aktif di Jawa Timur sebesar 64,133.347 orang, peserta KB Aktif mengunakan KB Suntik 1180 orang,(54,35\%). Peserta KB PIL 223 orang,(28,75\%). Peserta KB Implan 1285 orang,(49,90\%)peserta KB IUD 117 orang,(5,4\%). Peserta KB Kondom 116 orang, (5,4\%). Peserta KB MOW 61 orang,(1,05\%). Peserta KB MOP 320 orang, $(0,02 \%)$.

Penyebab keputihan sangat

bervariasi antara lain : jamur, bakteri, virus dan candidas. Keputihan yang di alami oleh akseptor KB suntik di sebabkan oleh pemakaian KB suntik lama, pengaruh perzonal hygiene, dan lingkungan.

\section{METODE}

Jenis penelitian yang di gunakan adalah observasional analitik karena penelitian tidak memberikan perlakuan kepada responsi. Dalam penelitian ini penelitian hanya menggunakan rekam medik,observasi pada responsi tanpa memberikan perlakuan sebelumnya. Penelitian ini menggunakan desain penelitian cross sectional dan dilakukan di BPS Ny Endang, Jln Rungkut surabaya pada bulan juni s/d september 2011. Populasi dalam penelitian ini adalah akseptor $\mathrm{KB}$ suntik 3 bulan yang melakukan kunjungan di BPS $\mathrm{Ny}$ Endang,pada bulan Juni - September 2011 yaitu sebesar 396 akseptor, sedangkan sampelnya adalah akseptor KB suntik 3 bulan yang berkunjung di BPS Ny Endang, pada bulan Juni - 
September 2011 yaitu responden Sebesar

25 akseptor dengan menggunakan teknik

Simple Random Sampling. Analisis data

dengan mengunakan uji chi-Square.

\section{HASIL PENELITIAN}

Berdasarkan hasil penelitian diatas didapatkan bahwa sebagian besar dari 25 akseptor KB suntik 3 bulan (DMPA) dengan lama pemakaian $\mathrm{KB}$ suntik 3 bulan $>1$ tahun $\quad$ sebesar 11 responden(84\%) mengalami flour albus patologis dan 2 responden (17\%) tidak mengalami flour albus patologis. Dan lama pemakaian $\mathrm{KB}$ suntik 3 bulan $<1$ tahun sebesar 10 responden $(85 \%)$ mengalami flour albus patologis dan 2 responden (16\%) tidak mengalami flour albus patologis.

Menurut Ari Sulistyawati
2011,bahwa dari lama pemakaian
kontrasepsi 3 suntik (DMPA)yang lama
dapat menyebabkan flour albus patologis
karena adanya kandungan estrogen dan
progesteron di dalamnya,hormon

ekstrogen dapat meningkat kadar glukosa,glukosa diubah menjadi glikogen. Hormon progesteron merangsang penyimpanan glukosa sebagai glikogen. Glikogen di ubah laktobasilus menjadi asam laktat sehingga lingkungan semakin asam yang merupakan tempat tumbuh jamur candida albican yang menyebabkan terjadinya flour albus patologis.

Dari 25 akseptor, lama pemakaian KB suntik 3 bulan (DMPA), didapatkan 21 akseptor (84\%) yang mengalami flour albus patologis, dan sebagian kecil yaitu 4 akseptor (16\%) yang tidak mengalami flour albus patologis.

Flour albus patologis disebabkan karena oleh berbagai macam faktor diantaranya : Keseimbangan Hormonal dan kontrasepsi hormon yaitu lama pemakaian $\mathrm{KB}$ suntik 3 bulan (DMPA),infeksi,parasit,virus. Berkaitan dengan teori flour albus patologis yang di alami oleh akseptor KB suntik 3 bulan 
(DMPA),karena keseimbangan hormonal dan kontrasepsi hormon.

Dengan Uji Chi-Square dengan menggunakan SPSS di ketahui hasil sebesar $X^{2} 1,009$ dengan signifikan 0,328 $\left(\mathrm{P}>\mathrm{X}^{2} 0,05\right.$ signifikan 3,841) maka $\mathrm{H}_{0}$ ditolak dan $\mathrm{H}_{1}$ diterima artinya ada hubungan antara lama pemakaian $\mathrm{KB}$ suntik 3bulan(DMPA)dengan kejadian flour albus patologis.

\section{Daftar Pustaka}

Arikunto S,2009, Prosedur Penelitian Suatu Pendekatan Praktek, Jakarta : Rineka Cipta .

Ari Sulistyawati,S,Si.T "pelayanan keluaraga berencana". Hak cipta@2011 penerbit Salemba Medika. Jakarta.

Dr,Ida Ayu Chandranita Manuaba,SpOG,"Memahami kesehatan Reproduksi Wanita, "(penerbit buku kedoktern egc,2009)."

Hartanto H, 2004, Keluarga Berencana Dan Kontrasepsi, Jakarta : Pustaka Sinar Harapan

Manuaba IBG,2008, Ilmu Kebidanan, Penyakit Kandungan, Dan Keluarga Berencana Untuk Pendidikan Bidan, Jakarta : EGC
Teori keputihan muncul

dikarenakan adanya peningkatan hormonal selama mengunakan KB suntik 3 bulan $>1$ tahun. Dalam hal ini vagina akan mengeluarkan cairan berwarna kuning kehijauan,gatal-gatal serta berbau. Cairan akan bertambah banyak seiring dengan lama mengunakan $\mathrm{KB}$

Manuaba IBG, 2007, Memahami Kesehatan Reproduksi Wanita, Jakarta : Arca

Notoatmodjo, 2005, Metodologi Penelitian Kesehatan, Jakarta : Rineka Cipta

Nursalam, 2008, Konsep Dan Penerapan Metodologi Penelitian Ilmu Keperawatan, Jakarta : Salemba Medika

Nana sudjana dan ibrahim 2004. Penilitian dan penilaian pendidikan, Bandung: pustaka pelajar.

Priyo Hastono,Susanto 2007, Modul Analisis Data,Fakultas kesehatan ,universitas Indonesia.

Prof,dr,Ida Bagus Gde Manual SPOG,kebidanan penyakit kandungan keluarga berencana untuk pendidikan bidan(jakarta EGC,2008)

Sianturi, 2006, Keputihan, Jakarta : FKUI 